\title{
Transnational Affinities and Invented Traditions: The Napoleonic Wars in British and Hanoverian Memory, I8IS-I9IS*
}

Thomas Hardy, arguably the foremost English novelist of the early twentieth century, often drew on the past for inspiration. He spent long hours in the British Museum researching accounts of the Napoleonic Wars, so as to lend an air of authenticity to the historical backdrop of his writings. Although Hardy's trademark descriptions of life in the fictitious county of Wessex are quintessentially English, they also reflect a fascination with the real-life German recruits who had left their fatherland to fight Napoleon under British colours. In contrast to a plethora of earlier Jacobite, Whig and Radical pamphleteers, he did not see the stationing of foreign mercenaries on British soil as an oppressive threat to the liberties of the English people, but rather imagined the King's German Legion (I803-I6) as a benign, albeit exotic, experiment in transnational bonding. A novella in which he first developed this idea, The Melancholy Hussar of the German Legion (I890), tells the story of a young woman who falls unhappily in love with a glamorous corporal of the eponymous unit, an ideal being ... with none of the appurtenances of an ordinary house dweller'. 'The tale of the two lovers struck a chord with newspaper publishers, who considered it commercial enough to be advertised as a 'brilliant story of the last century. ${ }^{2}$

The Melancholy Hussar betrayed subtle traces of the transnational cultural contact that the Revolutionary and Napoleonic Wars (I792-I8I5) had left behind in the British imagination. The apparent longevity of this memory and Hardy's contextualisation of his story in a literary discourse of melancholic loss interlock with historians' claims about the singular historical significance of the war experience. ${ }^{3}$ For Reinhart Koselleck, the Revolutionary period heralded a decline of

\footnotetext{
*The author would like to thank the anonymous reviewers of the English Historical Review, Brendan Simms, T.C.W. Blanning, Torsten Riotte and Andreas Stucki for their helpful criticism during the preparation of this article.

I. Thomas Hardy, The Melancholy Hussar of the German Legion and Other Stories (London, 2005), p. II9; G. Harvey, Thomas Hardy (Oxford and New York, 2003), pp. 38, II5-I6.

2. The Yorkshire Herald, I5 Nov. I890, 'A Brilliant Story of the Last Century'. For an analysis of Hardy's readership, see T.R. Wright, Hardy and His Readers (Basingstoke, 2003), esp. pp. 9-27.

3. I follow Kieran Klaus Patel here in defining 'transnational' as dialectic relationships between two or more national societies beyond the realm of pure diplomacy: K.K. Patel, 'Überlegungen zu einer transnationalen Geschichte', Zeitschrift für Geschichtswissenschaft, lii (2004), pp. 632-3.
} 
people's 'space of experience' (that knowledge which could be usefully applied from the past) in inverse relationship to the widening of their 'horizon of expectation' (the uncertain possibility of the not-yet). ${ }^{4}$ This rupture in the flow of time, the literary scholar Richard Terdiman adds, precipitated a 'memory crisis' that resulted in the alienation of Europeans from their heritage, and in an obsession with recovering the past. ${ }^{5}$ Not long ago, Peter Fritzsche went a step further by emphasising the pervasiveness of ruptured memory in order to accentuate the transcontinental connections formed by nostalgia across Europe and North America. ${ }^{6}$

The literary texts and memoirs that Terdiman and Fritzsche rely on for their arguments raise further questions about the functioning of the social and institutional frameworks within which ideas about nostalgia, as well as positive experiences of modernity, were articulated. ${ }^{7}$ Scholarship in the vein of the Anglo-German collaborative research project 'The Revolutionary and Napoleonic Wars in European Experiences and Memories' has recently begun to explore how the complex interplay of economic, social and mental factors influenced both popular perceptions of the wars against France and their long-term aftermath in collective memory. ${ }^{8}$ What remains a matter of contention is the agency and formative power of nationalist ideologies. There is a sense, as Fritzsche notes, that many of the alienated inhabitants of the nineteenth century sought solace in xenophobia and turned against the intellectual exchanges that had been characteristic of the Enlightenment. ${ }^{9}$ This claim derives from an unspoken, intuitive rather than rational, assumption based on the early appropriation of the anti-Napoleonic struggle by nationalist causes outside France. The nationalisation of memory has proved self-perpetuating in generating a privileged heuristic status for the nation-state at the expense of alternative perspectives, as the state of research on the battles of Leipzig (18I3) and Waterloo (1815) makes

4. R. Koselleck, 'Historia Magistra Vitae: The Dissolution of the Topos into the Perspective of a Modernised Historical Process', in id., Futures Past: On the Semantics of Historical Time, tr. K. Tribe (Cambridge, MA, I985), pp. 2I-39. On the perceived acceleration of historical time in the nineteenth century, see also R.A. Vieira, 'Connecting the New Political History with Recent Theories of Temporal Acceleration: Speed, Politics, and the Cultural Imagination in fin de siècle Britain', History and Theory, 1 (2011), pp. 373-89.

5. R. Terdiman, Present Past: Modernity and the Memory Crisis (Ithaca, NY, 1993), p. 3.

6. P. Fritzsche, Stranded in the Present: Modern Time and the Melancholy of History (Cambridge, MA, 2004), esp. p. 204.

7. On this point, cf. M. Levinger, 'The Birth of Modern Memory', Modern Intellectual History, iii (2006), p. I77; P. Mandler, review of Fritzsche, Stranded in the Present, ante, cxxi (2006), p. I22.

8. A. Forrest, E. François, and K. Hagemann, eds., War Memories: The Revolutionary and Napoleonic Wars in Modern European Culture (Basingstoke, 20I2). For more detailed information about the participants, publications, and conferences, see the project website at the York University Centre for Eighteenth Century Studies, http://www.york.ac.uk/inst/cecs/resprojects/nbi2.htm. Unfortunately, the German website has been taken down since the end of the project in 2009.

9. Fritzsche, Stranded in the Present, p. I29. 
clear: despite having been won by coalitions, a substantial and fairly fresh body of publications concentrates on the two battles' emblematic function in German and British national mythology respectively. ${ }^{10}$

In stark contrast, diplomatic historians have long accepted the centripetal quality of Allied coalition-building in I8I3-I5, which, in the words of Paul W. Schroeder, constituted nothing less than the turning point in the transformation of European international politics from a 'competitive and conflictual balance of power' to a more peaceful 'nineteenth-century concert and equilibrium.. ${ }^{11}$ Moreover, the new interest in histoire croisée and cultural-transfer analysis has generated a plethora of studies on various aspects of the Anglo-German relationship, from immigration patterns to student pacifism, showing that Britain and Germany were 'less internally coherent and more externally open-ended' than previous work treating the nation-state as the self-evident unit of enquiry would suggest. ${ }^{12}$ The existing literature, however, has been less successful at reconciling the substantial evidence of cultural entanglements and good will on the one hand with the xenophobic tendencies of post-Napoleonic memory and the escalation of political antagonism on the other. In the case of Britain and Germany, the key question as to why the two nations went to war with one another in I9I4 despite their various entwinements still demands more conclusive answers. ${ }^{13}$

Io. For a representative sampling, see K.A. Schäfer, 'Die Völkerschlacht', in E. François and H. Schulze, eds., Deutsche Erinnerungsorte (3 vols., Munich, 200I-2), ii. I87-8; W. Siemann, 'Krieg und Frieden in historischen Gedenkfeiern des Jahres 1913', in D. Düding, P. Friedemann and P. Münch, eds., Öffentliche Festkultur: Politische Feste in Deutschland von der Aufklärung bis zum Ersten Weltkrieg (Reinbek, 1988), pp. 298-320; U. Schneider, Politische Festkultur im I9. Jahrhundert: Die Rheinprovinz von der französischen Zeit bis zum Ende des Ersten Weltkrieges (I806-I9I8) (Essen, I995), pp. 52-65, 332-6; S.-L. Hoffmann, 'Mythos und Geschichte: Leipziger Gedenkfeiern der Völkerschlacht im I9. und frühen 20. Jahrhundert', in E. François, H. Siegrist and J. Vogel, eds., Nation und Emotion: Deutschland und Frankreich im Vergleich im I9. und 20. Jahrhundert (Göttingen, I995), pp. III-32; L. Colley, Britons: Forging the Nation, I707-1837 (New Haven and London, 1992), pp. 364-7; P. Shaw, Waterloo and the Romantic Imagination (Basingstoke, 2002), p. 2. Although Jeremy Black gives the Waterloo commemorations of Britain's allies their due, his recently published reflections on the great battle nevertheless adopt an all too familiar stance in positing that "Waterloo was an iconic battle for the British, a triumph of endurance that ensured a nineteenth-century world in which Britain played the key role': J. Black, The Battle of Waterloo: A New History (Cambridge, 2010), p. xi.

II. P.W. Schroeder, The Transformation of European Politics $1763-1848$ (Oxford, 1996), p. v.

I2. D. Blackbourn, "As Dependent on Each Other as Man and Wife”: Cultural Contacts and Transfers', in D. Geppert and R. Gerwarth, eds., Wilhelmine Germany and Edwardian Britain: Essays on Cultural Affinity (Oxford, 2008), p. I8.

I3. J. Rüger, 'Revisiting the Anglo-German Antagonism', Journal of Modern History, lxxxiii (201I), pp. 579-617, esp. p. 585. Rüger provides an excellent survey of the latest literature on Anglo-German history. See also P. Major, 'Britain and Germany: A Love-Hate Relationship?' and A. Fahrmeir, 'New Perspectives in Anglo-German Comparative History', both in German History, xxvi (2008), pp. 553-62 and 457-68. On the particularly pronounced simultaneity of cooperation and antagonism in the field of German and British colonial politics, see U. Lindner, 'Imperialism and Globalization: Entanglements and Interactions between the British and German Colonial Empires in Africa before the First World War', Bulletin of the German Historical Institute London, xxxii (20IO), pp. 4-28. 
The present article argues that the memory cultures of Britain and Hanover shed new light on long-term dynamics of cooperation and alienation that gave rise to these fateful dichotomies in Anglo-German history. For I23 years (1714-1837) England had closer relations with Hanover than with any other Continental European state while the two monarchies were ruled in personal union under the House of Guelph. T.C.W. Blanning, Brendan Simms and a small cohort of younger historians have uncovered many important aspects of the diplomatic, religious, scientific, economic and cultural links that emerged from what was initially a dynastic marriage of convenience, but as yet we know little about the afterlife of this bilateral heritage. ${ }^{14}$ Such reticence belies the richness of Anglo-Hanoverian dialogue in the realm of memory, and, more particularly, the ways in which transnational remembrance shaped the two societies even after the formal dissolution of the personal union with the death in 1837 of the last male monarch to inherit both crowns, William IV. It will be seen that their close collaboration in the wars against Napoleon conditioned not only how Britons and Hanoverians related to each other but also their respective histories. Rather than being mutually exclusive, internationalism and nationalism both moulded the process of historical remembrance well into the First World War.

To make sense of these developments and their ultimately alienating effect on Anglo-Hanoverian relations, Jan and Aleida Assmann's distinction between 'communicative' and 'cultural' memory offers a useful starting point. The former concept designates the living, embodied memory of social groups with first-hand knowledge of certain historic events. The Anglo-Hanoverian veterans of the duke of Wellington's army and their dependants partook of the same communicative memory for as long as the immediacy of the Napoleonic war experiences remained vibrant. When these personal networks faded away with the passing of their members, Waterloo entered the domain of cultural memory, an abstract mode of commemoration more reliant on mediation through official rituals and symbols that were liable to semantic change. This is not to say that the transition from one ontological state to the other was predetermined, because any attempt to apply Jan and Aleida Assmann's binary model in a schematic fashion would

I4. T.C.W. Blanning, “That Horrid Electorate” or "Ma patrie germanique”? George III, Hanover and the Fürstenbund of 1785', The Historical Journal, xx (I977), pp. 3II-44; B. Simms, Three Victories and a Defeat: The Rise and Fall of the First British Empire, I7I4-I783 (London, 2007); N.B. Harding, Hanover and the British Empire, I700-I837 (Woodbridge, 2007); T. Riotte, Hannover in der britischen Politik (I792-I8IS) (Münster, 2005); A.C. Thompson, Britain, Hanover and the Protestant Interest, I688-1756 (Woodbridge, 2006); H. Smith, Georgian Monarchy: Politics and Culture, I7I4-I760 (Cambridge, 2006); P.H.H. Draeger, 'Great Britain and Hanover, 1830-66', (Univ. of Cambridge Ph.D. thesis, 1998). For an overview of recent scholarship on Anglo-Hanoverian relations, see B. Simms and T. Riotte, eds., The Hanoverian Dimension in British History, 1714-1837 (Cambridge, 2007). 
risk distorting the complex dialectic between strategic forgetting and preservation that defined Anglo-Hanoverian memory. Yet introducing communicative and cultural memory loosely as overarching analytical categories helps to focus attention on some of the varied issues that this article addresses. ${ }^{15}$ The first part engages with the development of an Anglo-Hanoverian social space against the background of the two countries' political relationship in the first half of the nineteenth century. The second section expands on this social theme by examining more closely manifestations of an Anglo-Hanoverian communicative memory in charities for war victims and the collaboration of veterans in claiming public recognition for their wartime service. The third and longest section endeavours to account for the profoundness of Anglo-Hanoverian estrangement that nevertheless came to characterise both societies' attitudes to their military heritage in the second half of the nineteenth century, as demonstrated by debates in Britain about foreign enlistment during the Crimean War (1854-6) and Hanoverian responses to the reinvention of Prussian army traditions during the reign of Kaiser Wilhelm II (I889-1918).

In 1977, when the historian Waldemar Röhrbein first suggested the need for further research into the perpetuation of Anglo-Hanoverian cultural crossovers after the personal union, such an undertaking would have represented a Sisyphean and arbitrary task, given the wide dispersal of potential sources. ${ }^{16}$ As a consequence of the digitisation of archive catalogues and newspapers, it has now become possible to explore large amounts of data for relevant keywords with a speed that would have been unthinkable thirty-five years ago. A special debt is owed here to The Times online archive and the ever-expanding print-media holdings of the British Library that are being made accessible online. Read in combination with parliamentary debates, memoirs and secondary literature, they promise a richer understanding of the transnational legacy of the Napoleonic Wars in Britain and Germany.

\section{I}

The military hostilities that broke out between Revolutionary France and ancien régime Europe have recently been termed the first total war

I5. Since I use Jan and Aleida Assmann's two memory categories only in a very broad sense, it would go too far to elaborate on their theoretical intricacies and the transformative effect that their work has had on memory studies. See J. Assmann, Das kulturelle Gedächtnis: Schrift, Erinnerung und politische Identität in frühen Hochkulturen (Munich, 1992); A. Assmann, Erinnerungsräume: Formen und Wandlungen des kulturellen Gedächtnisses (Munich, 1999); A. Erll, Kollektives Gedächtnis und Erinnerungskulturen (Stuttgart, 2005), pp. 27-33, II2-18; G. Sebald and J. Weyand, 'Zur Formierung sozialer Gedächtnisse', Zeitschrift für Soziologie, xv (20II), pp. 174-89.

I6. W.R. Röhrbein, 'Zusammenfassung_oder: Was blieb von der Personalunion?', in id. and A. von Rohr, eds., Hannover im Glanz und Schatten des britischen Weltreiches (Hannover, 1977), p. 86. 
because of the unprecedented intensification of warfare after $1792 .{ }^{17}$ Although the electorate of Hanover was located geographically outside the immediate zone of danger, the perpetual campaigns that followed eventually caught up with Britain's Continental dependency. When the armies of Napoleon did arrive, the anglophile German principality was made to feel the full impact of the First Consul's bid for hegemony on the Continent. A French invasion under the command of General Edouard Mortier in May I803 secured the disbandment of the entire electoral army in the Convention of Artlenburg, and set in motion the flight of large numbers of disgruntled Hanoverians across the Channel. The British government supported the exodus materially, since it welcomed volunteers for the war effort against Napoleon. The 30,000 former soldiers, escaped draft-dodgers and prisoners of war who passed into the so-called King's German Legion (KGL) over the next twelve years won fame for their military achievements as well as iconic status in later narratives of the Napoleonic Wars. ${ }^{18}$ In I9Io, the amateur historian Adolf Pfannkuche stressed proudly in a popular history of the KGL that the 'feats of the Legion are what raised us from the ashes of an epoch of humiliation'. While he and many of his contemporaries looked with regret on Hanover's 'fateful' bondage to British diplomacy, he also had nothing but praise for Britain as a 'paragon of national liberty, a solid rock in the sea on which Hanoverians sought and found sanctuary' ${ }^{19}$

Ironically, at the time of the KGL's inception, opposition politicians in Britain painted King George III's subjects from the Continent as a royalist Praetorian Guard with ambitions to overthrow that national liberty. In making these accusations, they resuscitated old fears dating back to I742, I756 and I775, when Hanoverian troops had last been hired. The clash between legionnaires and Irish militiamen at Tullamore (I806), followed by the participation of Hanoverian troops in the flogging of militiamen protesting about the price of knapsacks in the Cambridgeshire town of Ely in I809, could not but fan the rhetorical

17. D.A. Bell, The First Total War: Napoleon's Europe and the Birth of Warfare as We Know It (Boston, MA, 2007), esp. p. 9. For stimulating discussions about the applicability of the concept to Revolutionary and Napoleonic warfare, see also R. Chickering and S. Förster, eds., War in an Age of Revolution, I775-I8I5 (Cambridge, 20IO).

I8. The particulars of recruitment to the KGL have been so thoroughly explored that I will refrain from further discussion. For details, see J. Mastnak, 'Werbung und Ersatzwesen der Königlich Deutschen Legion I803 bis I8I3', Militärgeschichtliche Zeitschrift, lx (200I), pp. II9-42; D.S. Gray, 'The Services of the King's German Legion in the Army of the Duke of Wellington, I809-I8I5' (Florida State Univ. Ph.D thesis, I970), pp. I-77.

19. A. Pfannkuche, Die königl. Deutsche Legion (King's German Legion) I803-18I6 (Hannover, I9IO), pp. 264-5. 
fire of Radicals such as William Cobbett. ${ }^{20}$ Because of such expressions of visceral opposition to the presence of the KGL in Britain, in addition to accusations of the preferential treatment that they received at the expense of native forces, the more upbeat histories of the unit—such as that of Pfannkuche-have attracted censure for being too nostalgic. ${ }^{21}$

It is argued here, by contrast, that the negative stereotyping of Hanoverians ignored the reconciliatory counter-pull of the transnational social space' (to borrow a term coined by Ludger Pries) that the legionnaires managed to carve out for themselves in English society. This comprised social practices, artefacts and symbols far exceeding any previous Anglo-Hanoverian interactions, which is precisely why republican Radicals were slow to make acknowledgements that could have been construed as retrospective approval for the I804 Foreign Enlistment Act of the Tories. ${ }^{22}$ In fact, the size of the emigrant legion, and the infrastructural investments needed for its accommodation, irrevocably changed the character of the local communities that hosted the recruits. Bexhill, a town of a mere $\mathrm{I}, 000$ inhabitants in south-east England, saw its population expand nearly threefold in August I804 with the arrival of four KGL infantry battalions. Although residents gave the foreigners a cool reception, the parish of St Peter's had already begun recording the first weddings by the end of the month. Regular bi-national social functions, and memorable traits of the Germans such as their fine singing and love of horses, did not fail to make an impression on the town's population, and notably its women, no fewer than I08 of whom entered into marriage with legionnaires before the KGL left Bexhill in August I8I4. ${ }^{23}$

20. N.B. Harding, 'Hanover and British Republicanism', in Simms and Riotte, eds., The Hanoverian Dimension in British History, p. 322. It appears, however, that the Irish militia started the altercation at Tullamore. Pro-German voices seized on this redeeming detail to exonerate the KGL after the Napoleonic Wars. Cf. D.S. Gray, "A Gross Violation of the Publick Peace": The Tullamore Incident, 1806, Irish Sword: Journal of the Military History Society of Ireland, xii (1976), pp. 298-30I; 'History of the King's German Legion', Athenaeum, cclx (I832), p. 675. On the hiring of Hanoverian mercenaries in the eighteenth century, see Simms, Three Victories and a Defeat, pp. 595-6, 609.

2I. Harding, 'Hanover and British Republicanism', p. 320; Morning Chronicle, I7 Nov. I8I7, 'To the Editor'; Harding, Hanover and the British Empire, p. 256.

22. Many of the KGL's field officers were familiar with the British army through their service in Gibraltar and India in the I780s and I790s, but, as Chen Tzoref-Ashkenazi has shown recently, Hanoverians maintained a cultural separateness from the British colonial establishment. The intensifying anglicisation of the Hanoverians after 1803 found outward expression in the introduction of English as the language of command: C. Tzoref-Ashkenazi, 'Hanoverians, Germans, and Europeans: Colonial Identity in Early British India', Central European History, xliii (20IO), pp. 22I-38. On Ludger Pries' definition of transnational space as constituted by social practices, see 'The approach of transnational social spaces: responding to new configurations of the social and the spatial', in L. Pries, ed., New Transnational Social Spaces: International Migration and Transnational Companies in the Early Twenty-First Century (London and New York, 200I), p. I8.

23. A. Uffindell and M. Corum, On the Fields of Glory: The Battlefields of the I8Is Campaign (London, 1996), pp. 328-9. 
The British army on campaign had occasion to deepen these bilateral encounters. Hanoverians participated in a range of far-flung missions in collaboration with ethnically British units; at Waterloo alone KGL regiments were dispersed among three separate army corps, while a relatively significant number of officers went on to obtain transfer into the British service proper by exchange or promotion. ${ }^{24}$ Evidence of benign 'otherness' impressed comrades of the other nationality all the more deeply on those occasions when it broke through the emotional desensitisation caused by the horrors of war to which armies were exposed on campaign. Captain Cavalié Mercer of the Royal Horse Artillery, whose memoirs remain one of the most detailed and lively eye-witness accounts of the 1815 campaign, observed: 'Affection for, and care of, his horse, is the trait, par excellence, which distinguishes the German dragoon from the English.' Significantly, the adoption of KGL cavalry training manuals served as a call for imitation of Hanoverian horsemanship, as did the perpetuation of more anecdotal evidence in autobiographies and newspapers. ${ }^{25}$ At the height of Chartist unrest, the Tory journal, Blackwood's Edinburgh Magazine, reflected on the discipline of the legionnaires in 1838 :

[The KGL's] general character and conduct had no slight influence on the British soldiery. The remarkable propriety of conduct exhibited by the Germans in general, whether under arms or off duty, their love of music, their freedom from riot or intoxication, their scientific knowledge, in a great many instances, of the more profound parts of their profession, and the striking skill, and even the perfection with which they performed the duties of parade and field days, were felt by the British as an example from which much was to be learned, and from which, when the first aversion of John Bull to all foreigners was got over, the national good sense learned a great deal. ${ }^{26}$

Admiration for certain Hanoverian traits complemented rather than contradicted British national pride. The author of the above lines supported cultural borrowing as a means to aid Providence in 'exalting England' above all other powers.

For similar reasons, Britain's German allies featured more prominently in popular commemorations of Waterloo than some modern historians seem

24. Of a total of I,350 KGL officers, 44 from the infantry and cavalry entered the British service in this way. Presumably this figure would have been higher still had promotion in the British army been by merit or seniority rather than purchase, which few Hanoverians could afford. In the KGL, advancement took place by the former method. N. Ludlow Beamish, History of the King's German Legion (2 vols., London, I832-7), ii. 629-31, 669-7I.

25. Cavalié Mercer, Journal of the Waterloo Campaign Kept throughout the Campaign of I8IS (I870; London, 1927), p. 42. Cf. Chums, I7 Oct. I894, 'The Pets of the Regiments'; F. von Arentsschildt, Instructions for Officers and Non-commissioned Officers of Cavalry on Outpost Duty, abr. F. Ponsonby (London, I844).

26. 'The King's German Legion', Blackwood's Edinburgh Magazine, xliii (1838), pp. 739, 743. 
prepared to admit. 'Revisionists' such as David Hamilton-Williams and Peter Hofschröer have tried to debunk the myth of a British victory by contending that British accounts in general, and Wellington's in particular, deliberately ignored the pivotal input of non-British forces. ${ }^{27}$ The festivities held to mark the thirty-fifth anniversary of the battle in the Lancashire town of Preston, on the other hand, indicate that the Germans formed part of an inclusive, one may go so far as to say grateful, commemorative discourse at the local level. Following established custom, the mayor hosted a lavish dinner for veterans of the Napoleonic Wars and resident notables in the Corn Exchange. Unsurprisingly, the toastmasters used the occasion to extol the gallantry of the British forces, but, more surprisingly, they also acknowledged the relatively small number of Britons present at Waterloo and praised the other national contingents. This was done to throw into even greater relief Wellington's outstanding deployment of a multinational coalition that comprised raw new levies from Belgium, Brunswick, Hanover, Nassau and the Netherlands. The effect was to suggest parallels with great generals of the preceding century, such as Eugene of Savoy and the duke of Marlborough, whose reputations derived in part from their successful management of coalition armies and the fame they had won not just nationally but throughout Europe. The glorification of Wellington notwithstanding, toasts to the KGL's 'gallant' defence of La Haye Sainte and the Prussian army's 'great service to the British troops' conveyed an implicit admission that victory had indeed been a close-run thing. If Waterloo anniversaries in Preston's Conservative circles showed any unique traits, it was in the elaborate way in which the prosperous citizens of this industrialising hub of cotton production celebrated the day. ${ }^{28}$ As one contributor to the United Service Magazine noted eloquently, "[f] or ages the Germans fought in the cause and service of England on many a glorious field, and the gallant legions of Hanover, till lately our own, have especially distinguished themselves under the British flag. Their reminiscences of victory are the same as ours, and their part in them was to the full as honourable and as glorious. ${ }^{29}$

27. Cf. D.H. Williams, Waterloo: New Perspectives. The Great Battle Reappraised (New York, I993), p. II; P. Hofschröer, I8I5 - The Waterloo Campaign: The German Victory. From Waterloo to the Fall of Napoleon (London, 1999), pp. 336-8.

28. The Preston Guardian, 22 June I850, 'Anniversary of the Battle of Waterloo'; D. Hunt, A History of Preston (Preston, 1992), pp. 193-4, 97-8. Most newspapers tended to provide only sparing descriptions of Waterloo anniversaries, but it is notable that in cosmopolitan Manchester, too, the municipal Waterloo dinner of 1849 displayed the flags of the Dutch-German allies at one end of the banquet hall: Manchester Times, I6 June I849. For contemporary comparisons of Marlborough and Wellington as managers of coalitions, see 'Marlborough No. II', Blackwood's Edinburgh Magazine, lviii (I845), p. 658; 'Eugene, Marlborough, Frederick, Napoleon, and Wellington', Blackwood's Edinburgh Magazine, lxi (1847), pp. 45-6.

29. Colburn's United Service Magazine, I855, Part I, p. III. 
To be sure, there were variations in the degree to which writers and anniversary celebrants acknowledged Britain's debt to foreign soldiersHanoverians certainly tended to be praised more than Blücher's Prussians, because of their service under Wellington's command-but the court and keen observers of Continental politics knew better than to marginalise the role that German troops had played in the victory over Napoleon. On the contrary, given Britain's limited military resources on land, excessive selfadulation posed the risk in their eyes of lulling Britons into a false sense of security and alienating former and potential future allies. However prejudicial this was to national self-esteem, the high-society newspaper The Morning Post nevertheless admonished its readers, just as the AngloHanoverian personal union was breaking up in June I837, that the public needed to learn the 'wholesome truth' about the dependence of the British Isles on faithful auxiliaries, and consequently the importance of 'keeping up that intimate connection' with Hanover 'so long as the frail and perishable nature of all human alliances will permit'. ${ }^{30}$

The Hanoverian authorities had long laid the groundwork for such overtures from London by preserving a bilateral space of memory in official commemorations of the Napoleonic Wars. The name for the site of Napoleon's final defeat was a telling indicator, as Hanoverians adopted the British 'Waterloo' rather than the Prussian 'Belle Alliance'. The popularisation of the term 'Waterloo' was expressive of a commitment to the British viewpoint for political as well as cultural reasons. Whereas the Peace Column constructed on Belle-Alliance Platz in Berlin in I840 reflected the dichotomous contextualisation of the 'Wars of Liberation' (I813-I5) in Prussia by drawing on both monarchical and bourgeois allegory, the use of 'Waterloo' reflected an unambiguous loyalty to the ruling house. ${ }^{31}$ Financed by voluntary subscription and the Hanoverian diet to generate a semblance of popular endorsement, a small group of courtiers oversaw the construction of the so-called Waterloo Column (I8I632) in Hannover to pay homage and curry favour with their sovereign. ${ }^{32}$ The monument celebrated 'courage and fidelity to king and fatherland' by semiotically branding the names of all Waterloo casualties with the Guelph coat of arms under a statue of Victory. What added a special twist to this exercise in monarchical legitimation was the fact that the dual royal titles of the dynasty were reflected at the dedication ceremony. Hanoverian soldiers visually affirmed the existence of the personal union by wearing scarlet tunics reminiscent of British uniforms, and by singing 'God save

30. Morning Post, 2I June I837, p. 6, 'The Kingdom of Hanover'.

31. U. Bischoff, Denkmäler der Befreiungskriege in Deutschland I8I3-I8I5 (2 vols., Berlin, 1977), ii. III-35; M. Lurz, Kriegerdenkmäler in Deutschland: Befreiungskriege (6 vols., Heidelberg, 1985-7), i. 222-4. On Prussian memory, see C. Clark, 'The Wars of Liberation in Prussian Memory: Reflections on the Memorialization of War in Early Nineteenth-Century Germany', Journal of Modern History, lxviii (1996), p. 552.

32. Since both the kingdom and the capital shared the same name, spelling is used to distinguish them. 'Hannover' designates the city. 
the King'. Afterwards the officers attended a dinner in a banquet hall that was decorated with the twin portraits of Wellington and the former field commander of the KGL, General Count Carl von Alten. ${ }^{33}$

Despite its elitist and military overtones, the anglicisation of Hanoverian identity also influenced bourgeois mainstream patriotism, where it acquired progressive political overtones. At the laying of the foundation stone for the national Hermann Monument in I84I, the delegation from Hanover affixed a commemorative plaque that acknowledged Britain's protection of persecuted patriots: 'To the King's German Legion, hero-brethren ... who, under Britain's colours, demonstrated German loyalty to their king and preserved the honour of his army for the fatherland. ${ }^{34}$ Although it was damaging, the way in which British public opinion sided with Denmark rather than the German Confederation in the First Schleswig-Holstein War (I84850) left Hanoverian liberals' faith in the fundamental benevolence of British foreign policy and in the commonality of Anglo-Hanoverian interests intact. London remained a useful ally against the conservative momentum emanating from the rulers of Russia, Prussia and Austria. Notables and middle-class entrepreneurs active in the German national movement therefore sought to counteract Russophile sympathies in their own country by raising donations during the Crimean War for Britain's 'cause of justice and civilization' against Russia. ${ }^{35}$

Hanoverian support for British military operations in the Crimea bore witness also to the intertwined evolution of Hanoverian and British memory even after the formal termination of the personal union. The British naval officer and travel writer Adolphus Slade, who passed through Hannover a couple of years after that event, was struck by ample proof of the Hanoverian army being 'essentially English in tone and feeling, and from its noble services under the Duke [of Wellington] [it] almost considers itself as still forming part of the British army. ${ }^{36}$ Stressing the historical connection with Albion allowed Hanoverian patriots to emphasise their own ancestors' sacrifices for the liberation of Germany from Napoleonic tyranny. They saw the attachment of the KGL to Wellington's forces as doubly liberating, because not only did this partnership secure military victory but it also acculturated the legionnaires

33. Bischoff, Denkmäler der Befreiungskriege, ii. 570-72. See also M. Bresemann, 'Des Königs Deutsche Legion I803-I8I6 und ihre Überlieferung in der königlich hannoverschen Armee bis I866', Zeitschrift für Heereskunde, xlix (1985), pp. I02-7.

34. Cited in B. Schwertfeger, Peninsula-Waterloo: Zum Gedächtnis der Königlich Deutschen Legion (Hannover, 1914), p. 9.

35. See the open letter from the Hanoverian Zeitung für Norddeutschland to the secretary of the Royal Commission Patriotic Fund, I3 Jan. I855, reprinted in Colburn's United Service Magazine, 1855, Part I, p. 276. Cf. the report from John Duncan Bligh to the earl of Clarendon, 23 May I854, reprinted in M. Mösslang, C. Manias and T. Riotte, eds., British Envoys to Germany, I8I6-I866 (4 vols., Cambridge, 2000-2010), iv. 230-32.

36. Adolphus Slade, Travels in Germany and Russia: Including a Steam Voyage by the Danube and the Euxine from Vienna to Constantinople, in I838-39 (London, I840), p. 37. 
to the 'liberal social customs' and the 'grand constitutional state-system' of England, according to the early twentieth-century KGL historian Pfannkuche. ${ }^{37}$ Even allowing for the fact that cultural transfer sometimes represented less a voluntary choice than a precondition for Hanoverian officers' survival in polite English society, Pfannkuche's assessment came very close to the image that veterans projected of themselves. ${ }^{38}$ The son and biographer of the KGL artillery commander, General Sir Julius (von) Hartmann, reminisced that his father had combined in himself 'the self-confidence of a scion of a Hanoverian civil service family and an English gentleman'. ${ }^{39}$ The career of the Jäger officer Schütz von Brandis underscored how intergenerational communication similarly moulded popular knowledge about the Napoleonic Wars in other families. Born into a military dynasty with ties to the KGL in 1826 , he left the Hanoverian service in 1854 to volunteer for the short-lived British German Legion in the Crimean War, before returning to his fatherland and taking part in the battle of Langensalza, eventually resigning his commission not long after the Prussian annexation of Hanover. In retirement, he wrote a history of the KGL that described in great detail the gentlemanly code of British officers and its centrality to the esprit de corps of their Hanoverian brethren. Brandis' views were representative of a predominantly aristocratic segment of society, whose pride in the army was only matched by their ingrained mistrust of Prussia. ${ }^{40}$

For these Anglophiles, playing the English card was above all a political and psychological ploy to keep Prussification at bay. Since the seventeenth century, Guelphs and Hohenzollerns had led an uneasy coexistence, fighting with or against each other as the international political situation demanded. Hanoverian 'particularists' never quite forgave Prussia for the temporary annexation of the then electorate in 1805 and hoped, instinctively, that the old ally Britain would again protect or at any rate not betray them in a political crisis. ${ }^{41} \mathrm{On}$ the

37. Pfannkuche, Die königl. deutsche Legion, p. 265.

38. Friedrich von der Decken, one of the founding fathers of the KGL, complained that upperclass Germans in London quickly had to adopt English dress and social conventions to offset 'the lack of patience for things foreign among Britons': Friedrich von der Decken, Versuch über den englischen National-Charackter (2nd edn., Hannover, I8I7), p. 276.

39. Julius von Hartmann, Der Königlich Hannoversche General Sir Julius von Hartmann: Eine Lebensskizze (Hannover, I858), p. I88. Hartmann was not the only senior Hanoverian officer to be characterised in this way. Carl von Alten's biographer Julius Runnebaum similarly described the KGL field commander as the ideal of an 'Anglo-Hanoverian gentleman': J. Runnebaum, General Graf Carl von Alten: Ein Soldat Europas (Hildesheim, 1964), p. I22.

40. Schütz von Brandis, Übersicht der Geschichte der Hannoverschen Armee von I6I7-I866, ed. J. von Reitzenstein (Hannover and Leipzig, 1903). Biographical details of the author are contained in the preface.

4I. G. Bartels, Preußen im Urteil Hannovers I8I5-I85I (Hildesheim, I960), pp. I09-II; D. Brosius, 'Hannover und Preußen vor I866', in R. Sabelleck, ed., Hannovers Übergang vom Königreich zur preußischen Provinz (Hannover, 1995), pp. 23-30; F. Köster, Hannover und die Grundlegung der preußischen Suprematie in Deutschland I862-I864 (Hildesheim, 1978). On the Prussian reasons for the annexation in 1805 , see B. Simms, The Impact of Napoleon: Prussian High Politics, Foreign Policy and the Crisis of the Executive, I797-1806 (Cambridge, 1997), pp. 280-85. 
fiftieth anniversary of the battle of Waterloo, amid the portents of an imminent Prusso-Austrian showdown in Germany, an anonymous pamphleteer reminded his readers: 'The shared royal house nurtured a feeling of kinship, which is still felt notably in [the duchy of] Bremen, where maritime trade has kept [this notion] alive among the people. Even now the populace would not be able to believe that the English ... would ever side against us in a general war. ${ }^{\prime 42}$ When conflict did break out one year later, the prediction about Britain's good intentions proved to be accurate, although there was little Whitehall could do to prevent the dethronement of Queen Victoria's hapless cousin, King Georg V, at the hands of Otto von Bismarck. Nevertheless it is testament to the endurance of the ideals embodied by the KGL that Hanoverian émigrés opted to form the first of two exile legions for the liberation of the fatherland in London, and that the daughter of the KGL's former colonel-in-chief, the duke of Cambridge, secretly agreed to help them find work in the United Kingdom. ${ }^{43}$ The particularist politician and grandson of a KGL general, Heinrich Langwerth von Simmern, lent his influential voice to the recruitment drive by imploring fellow Hanoverians not to deny their innate British 'life essence' at a time when the fatherland was in danger. ${ }^{44}$

\section{II}

The self-perpetuating references to the past in Anglo-Hanoverian relations that were made into the 186 os touch on an important but under-appreciated facet of post-Napoleonic collective memory. Several historians have contended that the strategies that European societies adopted in response to the human cost of war consisted of abstraction and anonymisation. They point to the phenomenon that few fallen soldiers, except officers, were given individual grave-markers, which reduced the nineteenth-century mourning process to one of 'complete individual dissolution'. ${ }^{45}$ The Achilles heel of this interpretation is not so much that it fails to account for instances of individual mourning, such as the listing of battle casualties on the Waterloo Column, but

42. 'Ein Bremenser', Die Teilnahme der Herzogthümer Bremen und Verden an der deutschen Erhebung gegen die Franzosenherrschaft und namentlich an der Schlacht von Waterloo: Eine Festschrift zur Feier des I8. Juni (Hannover, 1865), p. 4.

43. J. Heinzen, "The Guelph "Conspiracy": Hanover as Would-Be Intermediary in the European System, I866-1870', International History Review, xxix (2007), p. 265.

44. [Heinrich Langwerth von Simmern], Der Hannöverische Particularismus: Eine oratio pro domo (Mannheim, I867), pp. 9-I4.

45. T.W. Laqueur, 'Memory and Naming in the Great War', in J.R. Gillis, ed., Commemorations: The Politics of National Identity (Princeton, NJ, 1994), p. I5I. Cf. G.L. Mosse, Fallen Soldiers: Reshaping the Memory of the World Wars (Oxford, 1990), pp. 45-7; D.W. Lloyd, Battlefield Tourism: Pilgrimages and the Commemoration of the Great War in Britain, Australia and Canada, I9I9-I939 (Oxford, I998), p. 2I. 
rather that the evidence is restricted to war memorials. Other popular mechanisms for coming to terms with the death or maiming of soldiers, and especially a mnemonic dialogue founded on charity between the former allies, are thereby sidelined. The next section will explore that part of the bilateral social space in which Britons and Hanoverians remembered the trials of war together.

Philanthropy, as Eliza Renee Milkes has demonstrated in a study of the voluntary subscriptions to the Waterloo Fund after I8I5, was central to the commemoration in Britain of the victory over Napoleon. The subscription sermons delivered by sympathetic clergy reminded readers of the suffering amid the triumph, and encouraged non-combatants to redeem their feelings of guilt for having escaped death through donations. The Waterloo Fund dispensed the funds collected in this manner among disabled veterans and the poor widows of fallen soldiers to whom state pensions were not available. ${ }^{46}$ Philanthropists' consideration for the plight of women mirrored the success of wartime writers such as Anne Hunter, Isabella Lickbarrow, Mary Leadbeater and Amelia Opie in promoting a distinctly female perspective on the misery inflicted upon soldiers' families. Destitute war widows appealed to Georgian sensibilities doubly, because their vulnerability to material poverty and gendered sensitivity were considered to make the loss of loved ones all the harder for them to bear. ${ }^{47}$ King George III instructed the Treasury to make no distinction between the widows of British and foreign officers in the disbursement of pensions. The press followed the example of the government by investing the financial and emotional vulnerabilities of Hanoverian women with the aura of the familiar. ${ }^{48}$ Taking their cue from metropolitan news outlets, provincial broadsides such as the Newcastle Courant and Trewman's Exeter Flying Post reported in late 1828 the story of a KGL officer's widow and her three young children who had been compelled by poverty to apply for parish relief from the authorities of St George's in London. The circumstances of the 'unhappy lady' were not newsworthy for their exoticism but rather because they amounted to another 'of those painful instances of destitution that present themselves so frequently of late. ${ }^{49}$ The German widows of other deceased officers were particularly inclined to play on these sentiments when applying to the Waterloo Committee

46. E.R. Milkes, 'A Battle’s Legacy: Waterloo in Nineteenth-Century Britain' (Yale Univ. Ph.D thesis, 2002), p. 203.

47. S.C. Behrendt, "A Few Harmless Numbers”: British Women Poets and the Climate of War, I793-1815', in P. Shaw, ed., Romantic Wars: Studies in Culture and Conflict, I793-I822 (Aldershot, 200o), p. I4. C. Kennedy, 'From the Ballroom to the Battlefield: British Women and Waterloo', in A. Forrest, K. Hagemann and J. Rendall, eds., Soldiers, Citizens and Civilians: Experiences and Perceptions of the Revolutionary and Napoleonic Wars, I790-I820 (Basingstoke, 2009), p. I45.

48. British Library, Peel Papers, Additional MS 404I4, fos. 336-7, War Office memorandum concerning grant of pensions, I7 Feb. I835.

49. The Newcastle Courant, 27 Dec. 1828, 'Reverse of Fortune'. See also the reprint of the same article in Trewman's Exeter Flying Post or Plymouth and Cornish Advertiser, I5 Jan. I829. 
for relief-as late as $1838 / 9$, when the Waterloo Fund reverted to the Treasury, two of the three highest-paid annuitants resided in the kingdom of Hanover. ${ }^{50}$

Charity, however, did even more to bring British generosity to the notice of the Hanoverian lower classes. In the autumn of I8Is the managers of the Waterloo Fund contributed $£ 45,000$ in the 'Name of the People of the British Empire' to subscriptions raised for the wounded troops of Brunswick, Hanover, Prussia and the Netherlands in their own countries. This donation supplemented $£ 62,500$ sent to the Continent by the Westminster Waterloo Association some months earlier. With their munificence towards Germany, the royal princes and titled aristocrats in the Westminster Waterloo Association consciously recognised the ties of the royal family to that country. ${ }^{51}$ The size of the combined donations greatly exceeded what civic initiatives for destitute veterans in war-damaged Hanover could muster. By way of comparison, the King's German Legion Relief Fund, which officers set up in I819 for the benefit of their comrades from the ranks, paid out just $£ 10,500$ until 1836 , and by 1854 funds were running so low that the Hanoverian state parliament, the Ständeversammlung, had to step in. ${ }^{52}$ The government scarcely performed better. According to Gerhard Schneider, the top priority of the newly restored Guelph administration in Hanover was economic reconstruction rather than the provision of individual relief for needy veterans and their dependants. In this way, the blind spots of the social infrastructure in Hanover and the eagerness of British philanthropists to alleviate war-induced poverty came to complement each other harmoniously—so much so that Hanoverian officials received instructions in 1823 to stop prospective supplicants from embarking for London. ${ }^{53}$ The Crown transferred fiscal responsibility for most invalided veterans to the Hanoverian military treasury in I837, but Whitehall's continued disbursement of half-pay to KGL officers and pensions to the disabled survivors of late eighteenthcentury campaigns remained one of the more idiosyncratic legacies of the personal union. ${ }^{54}$

The unilinear flow of these philanthropic transactions begs the larger question as to how far the Napoleonic Wars reinforced a British sense of sociocultural superiority over the Continent. Undoubtedly, one important motivation for thinking about conditions in Hanover was pity for those not lucky enough to have been born Englishmen. Even writers as favourably disposed to Hanoverians as the Blackwood's

5o. Milkes, 'A Battle's Legacy', p. 196.

5I. Ibid., p. I85; Morning Post, I8 June I818, p. 2, 'Waterloo Subscription'.

52. N. Ludlow Beamish, Geschichte der Königlich Deutschen Legion (2 vols., Hannover, 1837),

ii. 526; C. Haase, Das Hannoversche Militair-Pensionswesen (Hannover, I854), p. 86.

53. G. Schneider, '...nicht umsonst gefallen'? Kriegerdenkmäler und Kriegstotenkult in Hannover (Hannover, 199I), pp. 33-5.

54. Haase, Das Hannoversche Militair-Pensionswesen, p. Io3. 
contributor cited earlier felt, ultimately, that while the humblest colony of England was gaining yearly in opulence, population and power, Hanover continued in the same degree of moral sterility to which it has been so largely condemned by nature'. ${ }^{55}$ General Friedrich von der Decken, one of the early recruiters for the KGL, countered from the vantage point of an outsider looking in on British society: 'National pride is a mighty engine that drives the actions of Britons; no nation ever possessed a more intense feeling of self-worth than these islanders. ${ }^{56}$ On the other hand, refugees from the Continent would not have won the kind of acceptance that they did without the benefit of countervailing forces acting against supremacist thinking in British society. Refuting Edward Said's notion of Orientalism, David Cannadine has recently resurrected an idea first developed in the writings of Joseph Schumpeter by claiming that the core paradigm of British national ideology during the phase of colonial expansion in the nineteenth century was not ethnic difference but 'class'. Read in this way, the interactions of Britons with other societies involved the negotiation of status similarities and the deliberate cultivation of affinities with élites in the extra-metropolitan world, as opposed to the insistence on collective dissimilarities. ${ }^{57}$ Although Cannadine's attempt to establish the primacy of horizontal dialogue across social hierarchies has been criticised for underestimating the continuing impact of race in modern British society (and other conflictual relations of identity), a class-based approach nonetheless goes a long way towards conceptualising AngloHanoverian cultural exchange. ${ }^{58}$ If anything, racial affinities based on the belief in a common Saxon heritage enhanced Hanoverian officers' acceptance in Britain, as long as the latter observed similar standards of professionalism and social etiquette, and the Protestant articles of faith. ${ }^{59}$

The opportunities provided by this perceived similarity were demonstrated by the steady advancement of the abler aristocratic émigrés, including Carl von Alten, his brother Victor, Sir Wilhelm von Dörnberg and others, to senior binational commands in the Peninsular War and at Waterloo. For these senior officers and their descendants, acceptance by British peers represented a source of great satisfaction. Anglo-Saxon comrades 'quickly and readily recognised the efficiency and capability of the immigrated [Hanoverians]', the great-nephew of

55. 'The King's German Legion', Blackwood's Edinburgh Magazine, pp. 740-4I.

56. Decken, Versuch über den englischen National-Charackter, p. I27.

57. D. Cannadine, Ornamentalism: How the British Saw Their Empire (Oxford, 200I), p. 8. On the importance of class in British imperialist ideology, see also B. Porter, The Absent-Minded Imperialists: Empire, Society, and Culture in Britain (Oxford, 2004).

58. See reviews of Cannadine, Ornamentalism, by A. Burton, American Historical Review, cvii (2002), pp. 497-8, and I.C. Fletcher, Victorian Studies, xlv (2003), pp. 532-4.

59. On English 'Teutomania', see P. Mandler, The English National Character: The History of an Idea from Edmund Burke to Tony Blair (New Haven and London, 2006), pp. 86-Io5. 
the KGL colonel Christian von Ompteda proudly observed, 'and looked on their officers as "gentlemen"'. ${ }^{60}$ General von Hartmann, who visited London in 1838 for Queen Victoria's coronation, likewise appreciated the warm welcome which he and his compatriots received from former comrades, the duke of Wellington and other 'important men'. He took this as confirmation that 'we Hanoverians, but particularly we legionnaires, are held in high regard by this great nation'. ${ }^{61}$ The annual Waterloo banquets at Wellington's London residence, Apsley House, afforded irregularly attending Hanoverian officers the opportunity to reciprocate by assuring the ageing duke that the 'old men' of their army made it a point to celebrate his birthday. ${ }^{62}$ They also joined representatives from other armies that had fought with or under Wellington to take a leading part in the funeral procession of their former commander in I852, as ceremonial bearers of his Hanoverian field marshal's baton. In so doing, the mourners reactivated transnational connections born out of a sense of shared military achievement and a powerful language of mutual understanding between Allied Waterloo veterans. ${ }^{63}$ Although their ranks were thinning by mid-century, the clout of the surviving officers increased in inverse proportion as they moved into leadership positions. Only the retirement of Hanover's last minister of war in 1866 brought the reign of these Anglo-Hanoverian veterans, and with it their social networks, to an end. ${ }^{64}$

Class solidarity and military comradeship extended in two directions. The cultivation of Anglo-Hanoverian affinities enabled officers to recognise each other's achievements in the Napoleonic Wars, and at the same time fashioned a joint platform for interaction with the public at large in efforts to honour the dead. The sacralisation of the Waterloo battlefield is a case in point. The central shrine to fallen Britons, Waterloo Church, was discreetly supranational in that it concomitantly housed commemorative plaques to the Hanoverian officers (and even rankers) who had died under Wellington's command. ${ }^{65}$ The farmhouse of La Haye Sainte, 'so gallantly defended' by the KGL, conjured analogous associations for British battlefield visitors, as did the Hanoverian Monument erected by KGL officers for their deceased brothers-in-arms

6o. Christian F. von Ompteda, A Hanoverian-English Officer a Hundred Years Ago, ed. L. von Ompteda, tr. J. Hill (London, I892), p. I73.

6I. Hartmann, Der Königlich Hannoversche General Sir Julius von Hartmann, pp. 196-7. See also Runnebaum, General Graf Carl von Alten, p. I29.

62. The Times, I9 June I85I, p. 5, 'The Waterloo Banquet'.

63. The French newspaper La Presse had noticed the transnational habitus of Waterloo veterans a few years earlier. See the issue of 22 June 1845 , p. 2. For a detailed description of the occasion, see The Lancaster Gazette and General Advertiser for Lancashire, Westmoreland and Yorkshire, 20 Nov. I852, p. 5, 'The Duke of Wellington's Funeral'.

64. For lists of high-ranking officers alive in the I850s and I86os, see The Times, 'The Waterloo Banquet', and Die Königlich Deutsche Legion und das Hannoversche Corps bei Waterloo: Ein Erinnerungskranz für das Land Hannover zum I8. Juni I865 (Hannover, I865), pp. 40-4I.

65. Milkes, 'A Battle's Legacy', pp. 350-5I. 
in 1818 . When two English gentlemen discovered the memorial in a state of neglect in the early I840s, they went to considerable lengths to apprise the appropriate authorities of the situation. 'I trust', Charles White, a former aide to the duke of Cambridge, explained to the adjutant general of King Ernst August, 'that my motives for troubling you will not be attributed to any other feeling than to the regret I should suffer at the record of so much valour being allowed to fall into decay for the want of a few timely repairs - and to my deep interest and veneration for all matters connected with a country where I met with so much kindness and hospitality.' ${ }^{66}$ The king did not doubt White's good intentions and promptly attended to the repairs.

Anglo-Hanoverian collaboration in the preservation of battlefield monuments was emblematic of wider efforts by survivors of the Napoleonic campaigns to assert entitlements to public recognition. Partnership promised palpable benefits that unilateral action did not, the most important of these being mutual validation. Veterans and their historians could not easily praise the martial prowess of their own side without appearing immodest or biased, but foreign endorsement was a different matter altogether. The German translator of N. Ludlow Beamish's History of the King's German Legion (1832-7; translated in I837) admitted as much in his foreword when he explained that the initiative of an Englishman had been needed to undertake such a book project because of the 'exaggerated modesty' of his countrymen. ${ }^{67}$ In acknowledgement of his services, surviving KGL officers presented Beamish with an appropriate gift, a finely crafted silver table centrepiece worth no less than $£ 900 .{ }^{68}$ Conversely, the attachment of the Hanoverians to Wellington's command in the Peninsula and at Waterloo made these foreigners a valuable source of information for British military chroniclers; Captain William Siborne, the infamous model-maker and author of the groundbreaking History of the War in France and Belgium in I8IS (1848), drew extensively on eyewitness accounts from KGL officers. ${ }^{69}$ The affiliation of the legionnaires with the British army furthermore ensured that respected soldiers were ready to speak up for Wellington when he faced criticism in Germany. His 'intimate friendship' with General von Hartmann, for instance, helped to calm the waves after some notoriously impolitic remarks about

66. Hannover, N[iedersächsisches] H[aupt-]St[aats-]A[rchiv], Hann. 4I, XXI, Nr. I58, Charles White to General Ernst von Linsingen, 27 Aug. 1840. See also the letter by Edmund Henry Plunkett in the same folder. Tellingly, too, the enterprising artist Louise B [onaist] catered to the tastes of British tourists on the battlefield after I8Is by painting souvenir ceramics with scenes of Waterloo Church as well as the Hanoverian Monument: Milkes, 'A Battle's Legacy', p. 378.

67. Translator's foreword, in Beamish, Geschichte der Königlich Deutschen Legion, vol. i, pp. $x i v-x v$.

68. 'The King's German Legion', Colburn's United Service Magazine, I852, Part I, p. 393. The trophy can now be seen at the National Army Museum in London (NAM.2004-08-I-I).

69. P. Hofschröer, Wellington's Smallest Victory: The Duke, the Model Maker and the Secret of Waterloo (London, 2004), pp. II8-19. 
Prussian discipline at Waterloo in $1836 .{ }^{70}$ Likewise, Hartmann played his part in defending the conduct of the British forces against outside criticism by rebutting claims put forth in the works of the French military historian General Maximilien Foy, author of Histoire de la guerre de la péninsule sous Napoléon (1827). ${ }^{71}$

Still, there was one issue on which Wellington and even the most loyal Peninsular veterans parted company; but this, too, served to keep the transnational comradeship of the old soldiers alive. For years the participants in the campaigns in Portugal and Spain lobbied unsuccessfully for a token of official recognition on a par with the Waterloo Medal (I8I6). In spite of his pre-eminent role in the Peninsular War, the duke blocked these advances because he considered the thanks of Parliament to have been sufficient, and Waterloo 'an occurrence of an extraordinary nature'. ${ }^{72}$ Raising the profile of the Iberian theatre of war sat awkwardly with his personal ambition to elevate Waterloo above all other victories, and so himself above other victors. Many veterans had missed out on this final battle by being stationed elsewhere and were galled to receive no outward mark of their achievements and long service. Tensions between Waterloo and Peninsular regiments consequently led to more than one serious riot. ${ }^{73}$

The termination of the Anglo-Hanoverian union had the unforeseen benefit of clearing the way for Hanoverian recognition of the KGL's Peninsular war record. On II May I84I King Ernst August issued a campaign medal (Kriegsdenkmünze) as a 'testimonial of the high and well-merited favour' in which the veterans were held, and recipients still on active duty had the initials KDM marked against their name on army lists. ${ }^{74}$ Contrary to all expectations, the king's gesture rekindled the friendship between the Hanoverian veterans and their frustrated British counterparts. Shortly after the promulgation of the decree, Major Christoph Heise of the Gardejäger-the same man who had egged on Beamish to write the History of the King's German Legion ${ }^{75}$ contacted the editor of the United Service Journal to emphasise that

70. Hartmann, Der Königlich Hannoversche General Sir Julius von Hartmann, p. I84; John Bull and Britannia, I4 June I856, p. 384, 'Death of a Peninsular Veteran'. The scandal occurred when the Prussian military establishment took offence at comments made by Wellington during parliamentary hearings on the abolition of corporal punishment in the British army. See 'Die Aussagen des Herzogs von Wellington über die Disciplin der preußischen Armee', MilitairWochenblatt, xxi (I836), pp. 97-IO2.

71. Hartmann, Der Königlich Hannoversche General Sir Julius von Hartmann, p. I84. Cf. Hartmann's 'Berichtigung einiger Ansichten über die Verhältnisse der englischen Armee', Hannoversches Militairisches Journal, ii (I832), pp. 88-II3.

72. L. Smurthwaite, 'Glory is Priceless! Awards to the British Army during the French Revolutionary and Napoleonic Wars', in A.J. Guy, ed., The Road to Waterloo: The British Army and the Struggle against Revolutionary and Napoleonic France, I793-1815 (London, 1990), p. I77. H. Strachan, The Reform of the British Army, I830-54 (Manchester, 1984), pp. I8-19.

73. S.H. Myerly, British Military Spectacle: From the Napoleonic Wars through the Crimea (Cambridge, MA, I996), p. 93.

74. 'Affairs at Home and Abroad', Colburn's United Service Journal, I84I, Part 2, pp. 406-7.

75. Beamish, preface, Geschichte der Königlich Deutschen Legion, vol. i, p. ix. 
[i]t would have afforded us [legionnaires] infinite delight, if we had been able, long since, to congratulate our brave comrades of the British service on a similar testimony of Royal favour, in appreciation of services, which in our case have now been so graciously rewarded by our Sovereign, and which we trust, will ere long be awarded to our old companions-in-arms, no less deserving of the honourable motto - Tapfer und Treu [Courageous and Faithful]! ${ }^{6}$

The United Service Journal, for its part, was quick to praise Ernst August's 'act of justice and grace', and joined the plea for Queen Victoria to emulate his example. Although the creation of the Hanoverian Peninsular Medal failed to sway Horse Guards and Parliament in the short term, it undoubtedly sped up royal authorisation of the Military General Service Medal in 1847, which vindicated Hanoverian and British veterans alike since the General Order imposed no restriction on binational eligibility. More than I,300 Hanoverian veterans went on to apply for the Military General Service Medal. ${ }^{77}$ The two respective Peninsular awards in this way paid conspicuous tribute to the collaborative spirit of British and Hanoverian discourses about military valour far into the mid-nineteenth century. ${ }^{78}$ The way in which the veterans chose to share valour rather than to divide up martial achievement along strictly national lines had a knock-on effect on the British public sphere, where bourgeois entertainment media such as Slade's travelogues and Robert Burford's popular Waterloo panoramas in Leicester Square, London, accorded Hanoverians a prominent place in Wellington's victories. ${ }^{79}$ No such reminders were needed in Hanover, since the veterans of the King's German Legion considered themselves to be a living monument to British military traditions on the Continent, earning them the nickname 'the Englishmen' among their half-admiring, half-jealous countrymen for their feats against Napoleon in Spain and Sicily. ${ }^{80}$

76. 'Affairs at Home and Abroad', p. 406.

77. Smurthwaite, 'Glory is Priceless!', p. I72. For further details on the applicants, see also NHStA, Hann. 38D, Nr. I24I.

78. It similarly says a great deal about the extent of the overlapping conceptions of valour that Sir Nicholas Harris Nicolas, chancellor of the Order of St Michael and St George in I840, chose to include the Hanoverian Order of the Guelphs in his four-volume compendium of British knighthood orders, on account of its conferral on so 'many hundreds of British Subjects': Nicholas Harris Nicolas, History of the Orders of Knighthood (4 vols., London, I842), vol. i, pp. 1-li.

79. Robert Burford and H.A. Barker, Description of a View of the Battle of Waterloo: With the Disposition of the Troops Engaged in the Action, Fought on the I $8^{\text {th }}$ of June I8Is. Now Exhibiting at the Panorama, Leicester Square (London, I842). See also the review of a second panorama by Burford in Colburn's United Service Magazine, I852, Part 3, p. 582; Slade, Travels in Germany and Russia, pp. 37-4I.

8o. Hartmann, Der Königlich Hannoversche General Julius von Hartmann, pp. 156-7, I6I, 174. See also id., Lebenserinnerungen: Briefe und Aufsätze des Generals der Cavallerie Julius von Hartmann (Berlin, I882), pp. I2-I9. 


\section{III}

The prolonged struggle of Peninsular veterans for recognition illustrates how politics subtly, yet decisively, set the parameters of public debate about the Napoleonic Wars. The further Britain and Hanover moved away in time from the personal union, the more ideological points of reference and the significance attached to particular events were bound to shift. To draw out some of these developments in cultural memory, the last part of this article will examine the transition of Anglo-Hanoverian military comradeship from a transnational social space to the (attempted) construction of 'invented traditions'. Eric Hobsbawm and Terence Ranger wrote that invented traditions are sociological responses to 'novel situations which take the form of reference to old situations, or which establish their own past by quasi-obligatory repetition'. ${ }^{81}$ In practice, of course, the cultural engineers of fabricated customs in the nineteenth century often operated within time-honoured conventions already calibrated to regulate and solve recurring problems. The tragic story of the so-called British German Legion during the Crimean War exemplifies the intersection of genuine historical continuity, adaptive invention and partisan politics that would turn the Hanoverian legionnaires from an asset into a liability for Anglo-German relations in the second half of the nineteenth century.

In I854, suspicion of Russian autocracy and a resurgent sense of Britain's global greatness led the Peelite-Liberal administration of the Earl of Aberdeen to engage in the first major war between the European powers since I8I5, an event for which the country was woefully unprepared. It soon became apparent that no fewer than 90,000 new recruits were needed to augment the army's peacetime establishment of I0O,000 men. ${ }^{82}$ The recruitment crisis was disconcerting, but Cabinet and Parliament could relate to it historically by applying the perceived lessons of eighteenth-century manpower shortages and, most recently, the French Wars. The notion of historia magistra vitae still loomed large because the army's basic method of recruitment-voluntary enlistment and the hiring of foreign troops-had not changed much in the previous hundred years. Economic boom conditions and employers' fear of adverse effects on the availability of labour hampered recruitment in Britain, and therefore forced the government to give more thought to the time-honoured remedy of foreign enlistment. Aberdeen's ministry initially hesitated to put legislation to that effect before Parliament, lest the recruitment of mercenaries from the Continent arouse longstanding suspicions about reactionary designs to overthrow liberty in

8I. E. Hobsbawm and T. Ranger, 'Introduction: Inventing Traditions', in eid., eds., The Invention of Tradition (Cambridge, I983), p. 2.

82. Strachan, Reform of the British Army, p. 56. 
Britain. Although the Prime Minister's predictions were not far off the mark, the recent disintegration of the Tories and the subsequent collapse of the old party system caused the Foreign Enlistment Bill to be received in a political climate that deviated sharply from previous debates. In the House of Lords, where the Secretary for War, the duke of Newcastle, introduced the bill first to test the waters, the most heated exchanges took place between Peelites and Conservatives, whose political pedigrees stretched back on both sides to the Tory foreign enlistment statutes of I794, I804 and I806.

The one, albeit contested, constant in the discussion about the viability of hiring aliens was the precedent set by the KGL. Newcastle, a Peelite, envisaged the initial force of 15,000 men as simply reprising the role of the illustrious Hanoverians. The chief interlocutor for the Conservatives, the earl of Ellenborough, retorted in an overtly Whiggish, almost Radical, manner that the employment of foreigners, who could be called out to suppress riots, was contrary to all constitutional principles. He stressed, moreover, Newcastle's faulty historical reasoning, since the Hanoverians of $\mathrm{I} 80 \mathrm{O}$ had been allies in a joint cause, unlike the despised Hessians of the eighteenth centurywho the mercenaries required for the Crimean campaign resembled more closely. To sink the enlistment bill once and for all, Ellenborough appealed to British patriotism by dismissing the inferior discipline of foreign, notably German, soldiers. Instead of rising to the bait, the duke of Richmond, a former Ultra-Tory who had broken ranks over Catholic Emancipation, immediately went to the defence of the KGL's record, since he thought it an 'act of justice' to remember that 'on no occasion was that Legion second to the British army either in zeal or gallantry'. ${ }^{83}$ And Richmond did not remain the only commentator to take issue with Ellenborough's assertion. Enraged, Beamish immediately fired off letters to the editors of both the left-leaning Morning Chronicle and the United Service Magazine with contrary testimonies from eminent British generals. ${ }^{84}$ John Duncan Bligh, the British envoy to Hanover, meanwhile appeased hurt Hanoverian pride by blaming the course of debates in Parliament on politicians' 'overweening vanity' in the pursuit of victory for their party. ${ }^{85}$

The leader of the Conservatives, the earl of Derby, quickly sensed that his associate had overplayed the party's hand and changed tack. He conceded in the Lords that the Hanoverians had performed with equal distinction to the other members of the British army, but only because they were 'almost countrymen' anyway. To salvage Ellenborough's

83. 3 Hans cxxxvi (I4 Dec. 1854), 257-63.

84. Morning Chronicle, 26 Dec. 1854, 'To the Editor'; Morning Chronicle, 28 Dec. 1854, 'To the Editor'; 'The King's German Legion', Colburn's United Service Magazine, I855, Part I, pp. 246-50. 85. John Duncan Bligh to the earl of Clarendon, 30 Dec. 1854, cited in Mösslang, Manias and Riotte, British Envoys to Germany, iv. 232. 
critique concerning the dissimilarity of the KGL and the proposed foreign legion, he continued that the Hanoverian legionnaires had been no foreigners at all as 'subjects of the Sovereign of this country, whose battles they were fighting' ${ }^{86}$ In pursuing this line of argument, Derby replaced Newcastle's invented tradition with one of his own. The Act of Succession of 1700 and a complementary act passed at the accession of George I made a clear distinction between the subjects of the Crown in the British Isles and those on the Continent. True, Derby would have been unable to claim this kinship had there not already been uncertainty about the standing of Hanoverians in British law, but with his bold interpretation he pre-empted, perhaps even prefigured, a Home Office ruling of 1909 , some sixty years later, that Hanoverians had enjoyed the privileges of natural-born British subjects until the separation of the two crowns. ${ }^{87}$

Given a choice between two doubtful historical precedents, the Lords came down on the side of the incumbent government. Following a three-day debate in the Commons in which the Hanoverian legionnaires were barely mentioned, save for Sir Edward Bulwer Lytton's reminder of the widespread hostility to the formation of the KGL, the bill passed into law. The 1854 Foreign Enlistment Act deviated appreciably from its 1804 predecessor in so far as it prohibited the employment of the enlistees for policing duties in the United Kingdom and precluded officers' entitlement to half-pay when their period of active service expired. ${ }^{88}$ The financial provisions of the act were pitched too low to attract the most seasoned soldiers and therefore reduced from the start the likelihood that the new mercenary corps would ever emulate, as Queen Victoria hoped, 'the reputation of the King's German Legion, so long and so honourably associated with the British army in its most memorable campaigns' ${ }^{89}$ Thus the newly minted German, Swiss and Italian Legions failed to follow in the footsteps of their Hanoverian predecessors. They arrived too late in the Crimea to take part in the fighting and re-embarked for Britain disgruntled. One Italian contingent mutinied en route home and could only be persuaded at the last minute not to foment rebellion on the Calabrian coast against King Ferdinand II of Naples. Jägers of the German Legion clashed with British troops in an affray at Aldershot that left several dead. Soon thereafter, the Italians and Swiss disbanded under a cloud

86. 3 Hans cxxxvi (14 Dec. I854), $263-6$.

87. T[he] N[ational] A[rchives], P[ublic] R[ecord] O[ffice], HO 45/10399/179658, Superintendent of the Home Office registry to Customs and Excise, 28 May 1909. See also A. Fahrmeir, Citizens and Aliens: Foreigners and the Law in Britain and the German States, I789I870 (New York, 2000), pp. 44-5.

88. C.C. Bayley, Mercenaries for the Crimea: The German, Swiss, and Italian Legions in British Service, I854-I856 (Montreal and London, I977), pp. 5I-5.

89. The York Herald, I8 Aug. I855, 'The Queen's Visit to the Foreign Legion'; The Morning Post, i9 May I855. 
of controversy, but the Germans were permitted to stay on as military settlers in South Africa, only to cause further problems for the colonial administration there. ${ }^{90}$

The upshot of the Foreign Enlistment Act was the British government's decision never again to raise a European mercenary corps, because the extirpation of the 'legionary plagues' came at too high a price. ${ }^{91}$ In the sphere of cultural production the exotic appeal of the KGL retained a niche in the popular imagination, which military historians, Thomas Hardy, and intermittent proposals for the resuscitation of foreign legions drew upon. In 1900, the Scottish novelist Sir Herbert Maxwell still thought it necessary to counter the not uncommon predilection among British military chroniclers to count the Hanoverian troops at Waterloo as British with the injunction to recognise the entitlement of the Hanoverians, 'as Germans, to their share of honour in the result which they contributed so greatly to bring about'. In political terms, though, the Crimean fiasco damaged the reputation of the KGL beyond repair and so prompted a progressive devaluation in public appreciation of its achievements. ${ }^{92}$

In Hanover, the joint military heritage of the Napoleonic Wars seemed headed for a similar fate barely a decade later. The disbandment of the Guelph army in 1866, and with it the customs of the KGL, sent an unmistakeable signal that becoming Prussian demanded cultural assimilation into a 'community of forgetting. ${ }^{93}$ The lack of commonalities with Prussian military culture and its particularism made the Legion unattractive for commemoration, whereas 'Waterloo' fared somewhat better because of Prussian involvement in the battle and the consequent refashioning of the monarchical-transnational anniversary into a symbol of liberal nationalism. ${ }^{94}$ But, as Benedict Anderson has shown, the problem with complex 'imagined communities' such as nations is that enforced amnesia cannot be complete; suppressed

90. Bayley, Mercenaries for the Crimea, pp. II8-33. As a historical footnote, it is interesting to note that the resettled German legionnaires named one of their townships on the Cape 'Hanover': W.B. Tyler, 'The British German Legion, 1854-62', Journal of the Society for Army Historical Research, liv (1976), p. 29.

9I. Lord Clarendon cited in J. Laband, 'From Mercenaries to Military Settlers: The British German Legion, I854-186I', in S.M. Miller, ed., Soldiers and Settlers in Africa, I850-19I8 (Leiden, 2009), p. I2I. Cf. J.B. Conacher, Britain and the Crimea, 1855-56: Problems of War and Peace (Basingstoke, 1987), pp. 134-5.

92. Emphasis in the original: Herbert Maxwell, 'Our Allies at Waterloo', Nineteenth Century, xlviii (I900), p. 4IO. The Hanoverian position at La Haye Sainte Farm did in fact form an integral part of British battlefield travelogues into the I870s and I88os. See The Lancaster Gazette Supplement, 29 Dec. 1875, 'Christmas Day on the Field of Waterloo'; The Ipswich Journal, 20 July I878, 'The Eye Church Choir in Belgium'; The Leeds Mercury, 24 Jan. I885, 'Waterloo-A Visit to the Battlefield'.

93. Ernest Renan, 'Qu'est-ce qu'une nation?' et autres écrits politiques (I882; Paris, 1995), p. 228.

94. Bismarck: Die Gesammelten Werke, VIb, ed. F. Thimme (2nd edn., Berlin, I93I), document I508, pp. 249-50 (Bismarck to Count Otto zu Stolberg-Wernigerode, I7 Feb. I870); G. Schneider, 'Die Waterloogedenkfeier I9I5', Hannoversche Geschichtsblätter, xlv (20II), pp. 207-38; M. John, 'Liberalism and Society in Germany, I850-1880: The Case of Hanover', ante, cii (1987), p. 589. 
memories have a habit of resurfacing when socio-political power relations change, or the readmission of particular memories is deemed to be useful. ${ }^{95}$ Unlike his predecessors, Kaiser Wilhelm II was alive to the potential of Waterloo as a historical model, and initiated a controlled rehabilitation of Hanover's English heritage in order to serve his personal diplomacy at the turn of the century. In doing so, he initially shuttled quite seamlessly between foreign, national and local audiences. In addressing the British public in September I898, he carefully chose the evocative backdrop of the Waterloo Column to maximise the effect of his congratulations to the victorious forces of his grandmother, Queen Victoria, in the Sudan. Some months later, he issued a 'decree on tradition' (Traditionserlass) for domestic consumption which appointed sixteen Prussian regiments and battalions as the 'heirs' to the AngloHanoverian units present at Waterloo. In addition to satisfying his emotional curiosity about the country of his revered grandmotherand sealing a temporary rapprochement between Britain and Germany following from the Angola Treaty of August 1898-Wilhelm II counted on this second symbolic gesture to soften lingering resistance towards Prussian state-building in Hanover. ${ }^{96}$

The Traditionserlass gave a strong demonstration of the 'massproduced traditions' that defined the Kaiser's reign. ${ }^{97}$ Privately, members of the imperial entourage confessed that the blending of Prussian and Guelph military folklore had 'absolutely nothing' to do with the historic facts. ${ }^{98}$ In crucial contrast to the 1854 Foreign Enlistment Act, the far more manipulated reinvention of the KGL tradition did succeed in provoking a response. To show gratitude for the 'relegitimisation' of their past, veteran Hanoverian army officers presented the Kaiser with a miniature silver statue of the Waterloo Column on the anniversary of the great battle in I899. ${ }^{99}$ More importantly, bourgeois newspapers sided with the scandal-prone, impetuous monarch when he commended the Hanoverian and Prussian forces at Waterloo for having 'saved the British army from destruction' during the KGL centenary commemorations in 1903. The Pall Mall Gazette warned that '[w] ords are arrows which

95. B. Anderson, Imagined Communities: Reflections on the Origin and Spread of Nationalism (2nd edn., London and New York, I99I), pp. 199-203.

96. Berlin-Lichterfelde, Bundesarchiv, R43/I403, fo. I5Iv, Prussian interior minister to the German chancellor, secret, 27 Aug. I899; E. Schröder, Ein Tagebuch Kaiser Wilhelms II: I8881902 nach Hof- und anderen Berichten (Breslau, 1903), p. 306. For a discussion of Wilhelm II's complicated relationship with England, see J.C.G. Röhl, 'Der Kaiser und England', in W. Rogasch, ed., Vicky \& Albert, Vicky \& The Kaiser (Ostfildern-Ruit, 1997), pp. I65-86. On the diplomatic context, see L. Reinermann, Der Kaiser in England: Wilhelm II. und sein Bild in der britischen Öffentlichkeit (Paderborn, 200I), p. I83; H. Rosenbach, Das Deutsche Reich, Grossbritannien und der Transvaal (I896-1902): Anfänge deutsch-britischer Entfremdung (Göttingen, 1993), pp. 9I-II4.

97. E. Hobsbawm, 'Mass-Producing Traditions: Europe, I870-1914', in id. and Ranger, eds.,

The Invention of Tradition, pp. 263-307.

98. R. von Zedlitz-Trützschler, Zwölf Jahre am deutschen Kaiserhof (Berlin and Leipzig, 1924), pp. 56-7.

99. Schneider, '...nicht umsonst gefallen'?, p. I68. 
fly fast and far in these days', but the hostile reaction of the British media scarcely registered in Hanover, or, where it did, evinced little sympathy. ${ }^{100}$

The success of the Prusso-Hanoverian Waterloo myth and the simultaneous Anglo-Hanoverian estrangement stemmed from the convergence of two broad developments in the last thirty years of the nineteenth century. First, the British government's renewed partisanship for Denmark in the Second Schleswig-Holstein War (1863-4), as German patriots saw it, and the foundation of the Kaiserreich at the end of the Franco-Prussian War (I870-7I) accelerated a process of national differentiation which was reflected in the politicisation of Waterloo monuments. ${ }^{101}$ The proliferation of German war memorials for the casualties of the Franco-Prussian War, combined with the good care of the existing Hanoverian cenotaphs at Waterloo, put British patriots on the spot. To pay their fallen compatriots the same respect, Lord Vivian, the minister at Brussels, raised money in 1887 through various subscriptions in the United Kingdom and Belgium for a new Waterloo memorial at Evère. ${ }^{102}$ The competitive nationalist spirit of battlefield statuomania had a snowball effect on the domestic political mass market, where the sponsorship and refurbishment of monuments were traded for patriotic prestige - with sometimes amusing results. An architect tasked by the German embassy to carry out repairs on the Hanoverian Monument found to his great surprise on visiting Waterloo in April 1909 that the work had already been completed by an agent of the duke of Cumberland, the head of the deposed royal family of Hanover. The architect's chagrin was only exceeded by the disappointment of the imperial government and the provincial diet of Hanover, after two years of budget negotiations for the planned restoration. ${ }^{103}$

Second, the process of national differentiation facilitated a reconfiguration of nationalism in both countries. Fears about the future, engendered by worries over the consequences of domestic reform and Britain's increasingly precarious geopolitical situation,

I0o. Pall Mall Gazette, 2I Dec. 1903, 'The Unruly Member'. The Hanoverian socialists lampooned the supportive response of the bourgeois press in Volkswille, 22 Dec. 1903, p. 2, 'Die Traditionsfeierlichkeiten'.

IOI. The deteriorating image of Britain in Hanoverian public opinion comes through clearly in the envoys' reports to the Foreign Office. See Mösslang, Manias and Riotte, British Envoys to Germany, vol. iv, esp. pp. 26I-2.

I02. See correspondence relating to the monument at Evère in TNA, PRO, FO 10/655. On the 'nationalisation' of the Napoleonic Wars in Germany after I871, note F. Akaltin, Die Befreiungskriege im Geschichtsbild der Deutschen im I9. Jahrhundert (Frankfurt am Main, 1997), pp. II9, 28I. For details of the Prussian government's maintenance of the German monuments at Waterloo, see Berlin, Politisches Archiv des Auswärtigen Amtes, R I30489.

I03. See correspondence relating to the restoration of the Hanoverian Monument (I907-II) in NHStA, Hann. I22a, Nr. 3468, fos. 199-20I, 213-19, 220-22, 232, 242-3; Protokolle des 43. Hannoverschen Provinziallandtags (Hannover, I909), third session, I2 March 1909, pp. 52-4. 
led a diverse coalition of politicians and intellectuals to propose the fusion of the British motherland with her white settler colonies in a vast political-economic unit akin to a global nation-state. The idea of 'Greater Britain' militated against indulgence of the old AngloHanoverian space of memory, as the army's erstwhile dependence on auxiliaries from the Continent detracted from 'national efficiency' in imperial defence. ${ }^{104}$ Colonial rivalry also became a contributing factor in Germany, but the main reasons for the marginalisation of Hanover's cosmopolitan history were sheer ignorance about British affairs and the rise of 'homeland' (Heimat) ideology from the I880s. ${ }^{105}$ The Heimat banner, like 'Greater Britain' imperialism, mobilised a diverse array of activists, including environmentalists, proto-völkisch thinkers, agrarian anti-modernists, civil servants and liberal middle-class patriots, in defence of national 'character'. This enabled heimatlers to construct mythic pasts that were only secondarily governed by rules of historical fact. ${ }^{106}$ Hanoverian heimatlers could thus in 1903 're-remember' their ancestors fighting with the Prussians to save the British army at Waterloo, instead of seeing them as subordinates of the duke of Wellington, and hence part of the British war effort.

At the same time the Heimat idea followed its own logic, which sometimes conflicted with the original intent of the Kaiser's invented traditions. The failure to return the standards of the KGL to Hannover, after Wilhelm II had ordered them to Berlin for his personal inspection, set off a hard-fought campaign in early 1900 for their release. The Hannoversche Anzeiger, the provincial capital's largest daily newspaper, declared without hesitation that His Majesty's inconsiderateness represented a 'demonstration of unscrupulous centralisation'. The Kaiser eventually relented after Hannover's magistrate had lodged an equally plain protest note with the military commander of the province. ${ }^{107}$ These passionate complaints were a potent display of bourgeois and municipal

I04. Northern Echo, 6 April I900, 'Foreign Legions'; D. Bell, 'Imagined Spaces: Nation, State, and Territory in the British Colonial Empire, I860-1914', in W. Mulligan and B. Simms, eds., The Primacy of Foreign Policy in British History, I660-2000: How Strategic Concerns Shaped Modern Britain (Basingstoke, 2010), pp. 197-213; S. Attridge, Nationalism, Imperialism, and Identity in Late Victorian Culture: Civil and Military Worlds (Basingstoke, 2003), pp. 45-8.

I05. Media coverage of Britain decreased after the mid-century as official pre-censorship ceased and political commentators no longer used the United Kingdom as proxy for German issues they were not permitted to write about. In the late i88os Hanover hosted an English-language weekly, The Anglo-American, but its target readership were expatriates rather than Hanoverians: R. Muhs, 'Geisteswelten: Rahmenbedingungen des deutsch-britischen Kulturaustauschs im I9. Jahrhundert', in id., J. Paulmann and W. Steinmetz, eds., Aneignung und Abwehr: Interkultureller Transfer zwischen Deutschland und Großbritannien im I9. Jahrhundert (Bodenheim, I998), p. 6I.

I06. For a discussion of the historical malleability of the Heimat idea, see A. Confino, Germany as a Culture of Remembrance: Promises and Limits of Writing History (Chapel Hill, NC, 2006), pp. 57-80. Cf. also G.S. Williamson, The Longing for Myth in Germany: Religion and Aesthetic Culture from Romanticism to Nietzsche (Chicago, IL, 2004).

I07. Hannoverscher Anzeiger, 7 Feb. 1900; see the collection of clippings from this and other Hanoverian dailies in Hannover, Stadtarchiv, HR 39, Nr. I33, and, in the same folder, Magistrate of Hannover to the office of the commander of the X Army Corps, 24 Feb. I90o. 
self-assertion against the central government, which exposed cracks in the Prusso-Hanoverian consensus on the public commemoration of the Napoleonic Wars, and showed that local elites were willing to wrest political authority from the sovereign for the protection of their regional Heimat. Activism of this kind limited imperial interventions, yet also made it more difficult, ultimately, to imagine the KGL's place in history other than from a heimatlich perspective.

As Britain and Germany moved into the First World War, the centennial of Waterloo, far from moderating belligerent rhetoric, cemented Anglo-Hanoverian estrangement. Though the anniversary 'necessarily pass[ed] very quietly' in Britain, so as not to embarrass the French, The Times and the Daily Telegraph exploited the occasion to castigate Prussian militarism as a continuation of Napoleonic militarism - 'the negation of all law, of all treaties, and all rights'in order to cast their own nation now and then as the champion of liberty in Europe. ${ }^{108}$ Wellington's German troops were glossed over or lumped with the militaristic Prussians. One officer, who still smarted from the Kaiser's 'determined effort to produce discord in the universal recognition of Wellington's victory' in 1903, took out his anger on Hanoverians in the United Service Magazine by harping on the alleged cowardice of the Cumberland Hussars during the battle. ${ }^{109}$

Those slighted in this way repaid in kind, and on a much grander scale, for they did not have the feelings of allies to consider. In Hannover IOO,000 spectators gathered at the Waterloo Column to remember I8 June as a German victory won for the liberation of Europe. On the same day, the municipal Fatherland Museum opened a special Waterloo exhibition intended to highlight the commonality of purpose between the i8I5 campaign and the present war, namely the fight, in the words of the curator, for the 'fate of Europe, even the world, and above all the existence, future and honour of the German people, forever'. In keeping with the spirit of wartime Anglophobia, the centenary festivities played down the military role of Britain. In order to sidestep the nationally diverse composition of Wellington's divisions, the Fatherland Museum commissioned a large diorama depicting the defence of La Haye Sainte Farm with the aim of recreating an exclusively Hanoverian moment of glory. ${ }^{110}$ And yet, even at this point, their historical entwinement locked the former allies in a dialogue of sorts. The claim made by the

I08. The Times, I8 June I915, p. 9, 'Waterloo'; Daily Telegraph, i8 June i915, p. 8, 'Waterloo'. See also T.C.W. Blanning, 'I8. Juni I81s: Waterloo', in E. François and U. Puschner, eds., Erinnerungstage: Wendepunkte der Geschichte von Antike bis zur Gegenwart (Munich, 2010), p. 179 .

I09. R.H. Mackenzie, 'Some Words on Wellington and Waterloo', United Service Magazine, June I915, p. 267. Cf. also H. Belloc, 'The Effect of Waterloo', The Dublin Review, clvii (I915), p. I32.

IIO. W. Pessler, 'Deutsche Waterloo-Erinnerungen im Vaterländischen Museum der Stadt Hannover', Hannoversche Geschichtsblätter, xviii (1915), pp. 293-338; id., 'Die WaterlooJahrhundert-Ausstellung im Vaterländischen Museum der Stadt Hannover', Hannoversche Geschichtsblätter, xviii (1915), pp. 389-416. 
exhibition's organisers, that the 'warlike spirit' of the German warriors at Waterloo defeated Napoleon, was itself an implied rejoinder to the vilification of Prusso-German militarism by British propaganda. Moreover, the foreign distinctions and praise awarded to soldiers lost none of their symbolic capital as external confirmation of Hanoverian valour. 'And when King Edward's misguided heirs', the Hannoverscher Courier prophesied, 'will compare the accomplishments of the auxiliary peoples, whom they are employing against Germany in this war, with the services that German armies rendered them a hundred years ago, it is only to be expected that they will one day send the sorrowful cry across the Channel: Germany, Germany, give me back your legions!'11 In fact, by a twist of fate, Hanoverian regiments ended up doing the shouting across the wastelands of the Western Front as they taunted British regiments with the reminder that their ancestors had earned battle honours together once upon a time. ${ }^{112}$

In an interesting thought experiment, one scholar queried not long ago whether it is possible to extricate European lieux de mémoire such as Waterloo from their fundamental entwinement with national ideologies. ${ }^{113}$ The attempt to arrive at an ontological separation poses a major and perhaps ultimately unanswerable challenge. During the nineteenth century's 'age of nationalism', sites of memory and historical events that held meaning for several countries invariably mirrored or reinforced particular nationalist forms of memory. To escape the barren conclusion that partisan agendas prevailed requires us to address the issue from the other end, by interrogating how transnational social spaces and associated collective memories impacted on national polities. ${ }^{114}$ In this vein, this article has made a case for the points of convergence between the memory cultures that the war effort against Napoleon forged in Britain and her one-time German dependency, Hanover. It examined initially the social settings of these encounters in order to elucidate key areas of overlap in the remembered war experience after I8I5. Charity helped British philanthropists relate to the Continent in general and women in particular as fellow victims of the financial and psychological

III. Hannoverscher Courier, I8 June I9I5, no. 31834, evening edition, p. 5, 'Besuch von Waterloo'. On the importance of external validation, see also Prof. Dr. Goebel, 'Des Königs Deutsche Legion', Hannoverland, ix (I9I5), p. 70.

II2. M. Middlebrook, The Kaiser's Battle (Harmondsworth, 2000), p. 47.

II3. S.B. Frandsen, 'Schleswig: Ein Erinnerungsort für Deutsche und Dänen', in Henningsen et al., eds., Transnationale Erinnerungsorte, p. 32. For a historiographical overview of the problems involved in trying to pinpoint European memory, see C. Cornelissen, 'Die Nationalität von Erinnerungskulturen als ein gesamteuropäisches Phänomen', Geschichte in Wissenschaft und Unterricht, lxii (20II), pp. 5-16.

II4. On this subject see also Jan Werner Müller, who pleads for further analysis of the correlation between national memory and international relations: J.W. Müller, 'Introduction: The Power of Memory, the Memory of Power and the Power over Memory', in id., ed., Memory and Power in Post-War Europe: Studies in the Presence of the Past (Cambridge, 2002), pp. I-38. 
distress brought on by almost twenty-five years of uninterrupted warfare, just as the horizontal ties of 'class', professional respect, mutual political interests and the kinship of survivors maintained channels of communication among veteran officers. These were viable options because the invocation of Anglo-Hanoverian comradeship did not so much undercut as contribute to national pride and, in Hanover's case, particularist state-building.

On a second axis, the discussion has charted the evolution of the memory of the Napoleonic era over a hundred-year period in order to explain the remarkable degree of Anglo-Hanoverian alienation evident by 19I4. Philip Konigs insists (with a smidgen of deliberate hyperbole, to be sure) that the relationship with Hanover was simply 'forgotten' in London after I837 and that the British share in the victories of Minden, Salamanca and Waterloo was conversely 'more and more overlooked' by Hanoverians. ${ }^{115}$ The evidence rather suggests a pragmatic dialectic between forgetting and reinvention of the Anglo-Hanoverian military heritage. It suited British parliamentarians to recall the services of their 'almost countrymen' during the recruitment crisis of the Crimean War; but, when that approach failed, the KGL's image lapsed into nostalgic quaintness and, during the First World War, disregard. Across the Channel the Prussian annexation of Hanover relegated the KGL to the sidelines of official commemorations until Kaiser Wilhelm II's 'decree on tradition' brought about a reintegration in 1899 . Part of the imperial fascination with Hanover's military traditions sprang from their Englishness, even if the fin de siècle realignment of national discourse and the Kaiser's ambivalent Waterloo speech subsequently drowned out the dialogical undercurrent. Johannes Burkhardt's conclusion that the Napoleonic Wars shaped the collective mindset of the German leadership in the First World War can only therefore be accepted with reservations, because the invoked historical continuities were of the Hohenzollern government's own making, and nowhere more so than in Hanover, where the war of 1914-I8 marked the culmination of a quite recent refashioning of collective allegiance. ${ }^{116}$

Since the end of the Second World War the Anglo-Hanoverian memory space has made a comeback on new terms. Diplomatic and political considerations have taken the place of invented traditions in a political conversation that has transcended the bilateral plane to become truly West European. During her state visit to the Federal Republic of Germany in 1965, Queen Elizabeth II ostentatiously abstained from laying a wreath at the Waterloo Column so as not to offend French

II5. P. Konigs, The Hanoverian Kings and their Homeland: A Study of the Personal Union, I7I4-I837 (Lewes, I993), pp. I68-9.

II6. J. Burkhardt, 'Kriegsgrund Geschichte? I870, I813, I756-historische Argumente und Orientierungen bei Ausbruch des Ersten Weltkrieges', in id., J. Becker, S. Förster and G. Kronenbitter, eds., Lange und kurze Wege in den Ersten Weltkrieg (Munich, 1996), p. 8I. 
sensibilities. By way of compensation the British army sent six hundred bandsmen and pipers to entertain the Hanoverian public at the same venue for the one-hundred-and-fiftieth anniversary of Waterloo one month later. The reconciliatory, pan-European message of the symbolic act was not lost on the 50,000 spectators. 'The occasion', a correspondent of The Times mused, 'was indeed one to stir a mixture of feelings - nostalgia for one's own dashing military tradition now vanished, a genuine weakness for Britain rooted in Hanover's past, and pride in the fact that the new Germany was now welcomed back as an ally and comrade in arms on an equal footing.' ${ }^{117}$ As the tercentennial of the dynastic union (2014) approaches, the 'European dimension' of the Anglo-Hanoverian connection will once more take centre-stage in a $€ 5.5$ million exhibition to be hosted by the state of Lower Saxony. ${ }^{118}$

To some the Europeanisation of collective memory may seem little more than a pragmatic dictate of political necessity to buttress EU integration; for others it is also a genuine opportunity to challenge old certainties about the past. Sir David Wilkie's epic painting Chelsea Pensioners Reading the Gazette of the Battle of Waterloo (I822) throws into relief the potential for new insights even from sources that on the surface celebrate national achievement. Had Wilkie been concerned with the formative power of war in the making of Great Britain, as Linda Colley asserts in her inquiry into the roots of British identity, then the presence in the image of a moustachioed Hanoverian legionnaire and a 'negro of the band of Foot Guards, who was once servant to the celebrated Moreau, and accompanied him on his retreat through the Black Forest' poses a paradox - unless it is assumed that the artist conceived the British national community in such broad terms as to encompass German 'almost countrymen' and French deserters of slave descent. ${ }^{119}$ Entering into speculations upon whether Wilkie subscribed to such a view is beside the point, since the painting's protagonists and composition attest more fundamentally to the diverse mobilisation of manpower, unity of purpose and transnational networks of memory that the wars of I792I8I5 engendered among allies. These, rather than the sense of nostalgic loss perceived by Peter Fritzsche and others, may have emerged as the true long-term legacy of the nineteenth century's new historical sensibility.

\section{Historical Institute, University of Bern}

JASPER HEINZEN

I17. The Times, 26 June 1965, p. I0, 'Hanover remembers Waterloo'; Hannoversche Presse Hameln, 21 May 1965, 'Waterloo', clipping to be found in NHStA, VVP 17, Nr. 2035; Die Zeit, 28 May 1965, 'Was ist uns Waterloo?'.

II8. 'Landesausstellung 20I4: Niedersachsen plant historische Ausstellung: I7I4-Hannovers Herrscher auf Englands Thron', Niedersächsisches Ministerium für Wissenschaft und Kultur, http://www.mwk.niedersachsen.de/live/live.php? navigation_id=6257\&article_id=19060\&_ psmand=I9; Hannoversche Allgemeine Zeitung, 8 Dec. 2009, 'Ausstellung über Hannovers Herrscher auf Englands Thron'.

II9. Colley, Britons, pp. 364-7; A. Cunningham, ed., The Life of Sir David Wilkie with his Journals, Tours and Critical Remarks on Works of Art; and a Selection from his Correspondence ( 3 vols., London, I843), ii. 76-7. 